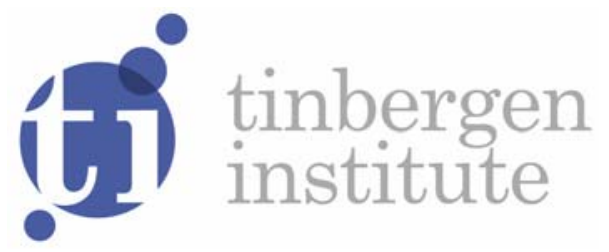

\title{
Car Ownership and Residential Parking Subsidies: Evidence from Amsterdam
}

Jesper de Groote Jos van Ommeren Hans R.A. Koster 
Tinbergen Institute is the graduate school and research institute in economics of Erasmus University Rotterdam, the University of Amsterdam and VU University Amsterdam.

More TI discussion papers can be downloaded at http://www.tinbergen.nl

Tinbergen Institute has two locations:

Tinbergen Institute Amsterdam

Gustav Mahlerplein 117

1082 MS Amsterdam

The Netherlands

Tel.: +31(0)20525 1600

Tinbergen Institute Rotterdam

Burg. Oudlaan 50

3062 PA Rotterdam

The Netherlands

Tel.: +31(0)10 4088900

Fax: +31(0)10 4089031 


\title{
Car ownership and residential parking subsidies: Evidence from Amsterdam*
}

\author{
By JESPER DE GROOTE, ${ }^{a}$ Jos VAN OMMEREN ${ }^{b}$ and HANS R.A. KOSTER $^{c}$
}

This version: 25 September 2015

\begin{abstract}
SUMMARY - Many cities around the world have introduced paid parking but implicitly subsidize parking for example by providing residential parking permits for street parking. We study the welfare effects of residential parking subsidies through changes in car ownership for Amsterdam. We employ a boundary-discontinuity design that exploits spatial variation in the length of waiting lists for permits and therefore in the size of the parking subsidy. In the city center, the waiting time for a permit is up to four years. Our results indicate that one additional year of waiting for a parking permit reduces car ownership with 2 percentage points corresponding to a price elasticity of car demand of -0.8 . We demonstrate that subsidizing residential parking induces a substantial welfare loss. On average, a parking permit induces an annual deadweight loss of $€ 270$. Furthermore, we show that the provision of parking permits is an income-regressive policy: rich households are five times more likely than poor households to receive these (implicit) parking subsidies.

JEL-code - R20, R40, R42

Keywords - parking policy, car ownership, household location choice
\end{abstract}

\section{Introduction}

During the second half of the $20^{\text {th }}$ century, car ownership levels have increased considerably in many countries around the world. Differences in car ownership levels between countries are still substantial as a result of differences in household income, gasoline and car taxation as well as public transport provision (Dargay et al., 2007; Dargay and Gately, 1999; Giuliano

\footnotetext{
* This paper has been presented at the 2013 Dutch Meeting of Economists in Amsterdam, the 2014 ITEA Conference in Toulouse and at the VU University. Seminar audiences are thanked for their useful input.

${ }^{a}$ Corresponding author. Department of Spatial Economics, VU University, De Boelelaan 11051081 HV Amsterdam, e-mail: j.de.groote@vu.nl.

${ }^{b}$ Department of Spatial Economics, VU University, De Boelelaan 11051081 HV Amsterdam, e-mail: jos.van.ommeren@vu.nl. The author is also affiliated with the Tinbergen Institute, Gustav Mahlerplein 117, 1082 MS Amsterdam.

${ }^{c}$ Department of Spatial Economics, VU University, De Boelelaan 11051081 HV Amsterdam, e-mail: h.koster@vu.nl. The author is also affiliated with the Tinbergen Institute, Gustav Mahlerplein 117, 1082 MS Amsterdam.
} 
and Dargay, 2006). Despite their success, cars are also associated with urban sprawl and negative external effects such as pollution and congestion (Glaeser and Kahn, 2004).

There is large spatial variation in car ownership within countries and cities. It has been extensively documented that car ownership levels in city centers are much lower than in suburban and rural areas, due to a combination of shorter travel distances, higher population densities, and better access to public transport, which makes car ownership less beneficial, (see, for example Button et al., 1980; Clark, 2007; Cullinane, 2002; Cullinane and Cullinane, 2003; Giuliano and Dargay, 2006; Handy et al., 2005; Ingram and Liu, 1999).

It is however largely unknown to what extent ownership levels are affected by residential parking policy (Guo, 2013). This is an important question because it is well known that around the world the price of residential parking is strongly reduced by policies. In most European cities, parking is subsidized through the provision of residential permits for parking on street, whereas in many US cities, parking supply is strongly increased through minimum parking requirements, resulting in cheap parking (Shoup, 1999; Van Ommeren et al., 2011).

The welfare consequences of these parking policies are likely minimal in locations where provision of parking is cheap. The opposite is true in city centers that have been evolved before the introduction of the car, such as the historic centers of most European cities. In these centers, on-street as well as off-street parking is extremely scarce and, not surprisingly, prices for both types of parking tend to be high. ${ }^{1}$

We will focus on the consequences of parking subsidies offered to residents in the center of Amsterdam, which was developed before 1800. Parking costs are high here: street parking costs $€ 5$ per hour, residential parking costs about $€ 3,600$ per year and a two-car garage costs about $€ 70,000$ (Cition, 2014; Van Ommeren et al., 2011). ${ }^{2}$ The demand for parking is distorted by the provision of residential parking permits which allow residents to park on street in the district where they live at a nominal fee of maximally $€ 400$ annually. ${ }^{3}$ Note that the residents still have to find a parking space, so they may still incur additional search and walking costs. The (implicit) subsidy associated with parking permits, about $€ 3,200$ per year, will then increase car ownership above the optimal level from a welfare perspective if all externalities due to car ownership and usage are internalized.

\footnotetext{
${ }^{1}$ In the US, on-street parking prices tend to be lower than prices of off-street parking offered by commercial providers. In European countries such as the Netherlands, on-street and off-street prices are about equal, as documented by Van Ommeren et al. (2014).

2 Van Ommeren et al. (2011) show that the full residential price of parking in the center is $€ 3,600$ per year, both for on-street and off-street parking, suggesting that both types of parking are close substitutes. Very few households park their car at the city fringe where parking is for free but where they have to pay the time cost of additional travelling. Households also have the option to park on street by buying a municipality parking pass for about $€ 12,000$ per year. Unsurprisingly, only a couple of households applied for this pass.

${ }^{3}$ The price of a parking permit differs between districts, but it is unrelated to car characteristics.
} 
In Amsterdam parking policy varies by district. In many parking districts the number of parking permits would far exceed the number of on-street parking spaces in case of unconstrained provision, inducing residential cruising for parking, particularly in the evening when residents come home from work (Van Ommeren et al., 2011). Households receive maximally one or two permits depending on the district they live in. In a number of onepermit parking districts, households also have to wait several years in order to obtain a parking permit. ${ }^{4}$ In the city center, the average waiting time is one year. Households that are on the waiting list for a parking permit are required to own a car and therefore pay the full (non-subsidized) price of parking. Consequently, the length of the waiting-list determines the (implicit) subsidy received by households.

To the best of our knowledge, this is the first empirical paper that aims to estimate the effect of residential parking subsidies on welfare through increases in household car ownership. In the theoretical economics literature that analyzes parking, car ownership is usually assumed to be given (e.g., Arnott and Rowse, 1999). In this literature, the focus is on the welfare effect of too low on-street prices, so parking for nonresidents is subsidized (see Arnott and Inci, 2006; Arnott and Rowse, 2009, 2013; Shoup, 2006). This reflects the US institutional setting, where on-street parking prices in many cities are far below commercial parking prices.

In contrast, we focus on an institutional environment, common in most European cities, where on-street and off-street prices are approximately equal, but where parking for residents is subsidized through the provision of residential parking permits. We estimate the effect of parking subsidies on welfare for the city center of Amsterdam by focusing on the effect of waiting lists for parking permits on car ownership. Waiting lists provide useful variation in the parking price for residents, because households have to live in the district and own a car to be on the waiting lists. This means they incur parking costs equal to the full market price while they are on the waiting list. ${ }^{5}$ The length of the waiting lists is not uniform over the city but varies by district (up to four years). The estimated effect of waiting-list duration allows us to derive the price elasticity of car demand. Previous studies indicate that the price elasticity of car ownership usually ranges between -0.1 and -0.5 (Whelan et al., 2000; Dargay, 2002). These rather inelastic demand elasticities for car ownership incorrectly suggest that the provision of parking permits in Amsterdam may only have a small effect, implying that the welfare effects of parking permit provision would be limited. However, we emphasize that these studies do not refer to demand elasticities in city centers. It is plausible

\footnotetext{
${ }^{4}$ Although many districts have parking permit constraints, the overall number of permits provided in Amsterdam is still almost equal to street parking supply. This makes sense in a city where there is very little off-street parking, and where demand for parking in the evening is mainly by residents.

${ }^{5}$ Parking permits are non-tradable, so it is very difficult to avoid the costs associated with waiting lists for parking permits. The only legal possibility for residents to evade the parking costs is to park the car in the free-parking districts at the fringe of the city, but this entails a lot of additional time costs. If this issue would be important, it would mean that the estimates of the deadweight loss are upper bounds.
} 
that the price elasticities in city centers will be higher, which would be consistent with the observation that car ownership tends to be lower in city centers.

In this paper, we use a cross-sectional identification strategy, which has the advantage that we can identify long-run effects of parking subsidies. The use of cross-sectional data, however, also has disadvantages if one is interested to measure a causal effect of parking policies on car ownership. In particular, it is plausible that spatial differences in car ownership levels are also due to household sorting based on household characteristics, in particular household income and size, as well as location characteristics such as population density, which are known to vary over space (Potoglou and Kanaroglou, 2008). Hence, in order to identify a causal effect, we control for a large range of household and location characteristics. Car ownership may also vary due to differences in unobserved household and location characteristics. To mitigate the problem of these unobserved characteristics, we employ a spatial boundary-discontinuity design (BDD), as introduced by Black (1999). The analysis hinges on the assumption that unobserved characteristics can be regarded as variables that vary continuously over space, while parking policy is district-specific and therefore varies discretely over space. Hence, our key identifying assumption to identify a causal effect of policy on car ownership is that household sorting at the boundary is continuous. 6 The identification strategy is useful to determine the effect of waiting-list duration on car ownership, but it is unable to capture the causal effects of paid parking on car ownership, because households residing in the paid-parking districts may park their cars outside the permit area in a free-parking district and walk to their homes and incur low additional costs. This is much less likely for households residing in the waiting-list districts near the city center because they are not allowed to park their cars in surrounding paidparking districts without waiting lists.

Our main finding is that car ownership is rather strongly reduced due to waiting lists for parking permits. Every year of waiting-list duration decreases car ownership by about 2 percentage points, which implies a price elasticity of car demand of -0.8 . The (implicit) subsidy of a parking permit (with an average waiting duration of one year) induces an annual deadweight loss of about $€ 270$ per permit, which is close to earlier findings by Van Ommeren et al. (2014). However, we measure residential parking demand, while the latter paper focusses on parking supply near shopping centers and ignores further indirect welfare implications of residential parking, like the loss of product variety in shops because of less convenient visitor parking, as suggested by Molenda and Sieg (2013).

Another important insight is that providing parking permits is an income-regressive policy. Households with an annual income of $€ 100,000$ are five times more likely to receive the subsidy provided by a parking permit than households with a minimum income.

\footnotetext{
${ }^{6}$ We will extensively check whether potentially unobserved household or area characteristics are correlated to the effect of waiting lists on car ownership in the sensitivity analysis, by excluding potentially important household characteristics, by including location characteristics, and by only focusing on rental housing. The results indicate that sorting is unlikely to be a problem here.
} 
The paper continues as follows. Section II introduces the model setup, Section III discusses the institutional context, Section IV provides an overview of the data, Section V shows the results and Section VI calculates the welfare effects. Section VII concludes.

\section{Institutional context: Amsterdam \\ A. Car ownership: stylized facts}

In the Netherlands, there are about 0.6 cars per capita for the population older than 18 years, which is comparable to other European countries. ${ }^{7}$ Car ownership in Amsterdam, which is the largest city of the Netherlands with about 800,000 inhabitants, is only 0.37 per capita. This is in line with the stylized fact that car ownership is lower in larger cities. In Table 1, it can be shown that car ownership has strongly increased in the last few decades in Amsterdam (by about 5 percentage points, or 13 percent over the last 20 years), but in the rest of the Netherlands the growth in car ownership has been at least twice as high. ${ }^{8}$ Notably, in contrast to the rest of Amsterdam, car ownership has remained stable in the city center over the last decades. At the end of the 1980s, car ownership was still higher in the center than in some other neighborhoods (East and West), but nowadays, ownership is the lowest in the city center.

There is a range of explanations for the relative decline of car ownership in the center. As (gross) income is a very good predictor for car ownership, one possible explanation is that neighborhoods have experienced different levels of income growth. However, household income differences between neighborhoods nowadays are extremely small (see Table A1 in the Appendix). ${ }^{9}$ Since 2005, increases in income have been quite uniform within Amsterdam (see Bureau Onderzoek en Statistiek, 2014). Before 2005, incomes have increased more rapidly in the center (see Bureau Onderzoek en Statistiek, 2007), so car ownership would have increased more strongly in the city center if income would be the only factor that determines car ownership. Another explanation is that the income elasticity of car demand is lower in the center. However, somewhat surprisingly, within-country studies suggest that the

\footnotetext{
${ }^{7}$ Slightly confusing, in the literature car ownership is measured either per household, capita, or adult capita, so for persons older than 18 years. In this section we provide data per adult capita. In the data analyzed later on we use car ownership per household.

${ }^{8} \mathrm{~A}$ similar development is observable in the other European countries. In London, car ownership per capita has even decreased from 0.43 to 0.39 , while in the UK it has increased from 0.54 to 0.59 over the last 15 years (London datastore, 2014, and UK government, 2013).

${ }^{9}$ In many European cities, an abundant supply of public housing in city centers induces the poor to locate in the attractive historic centers. In Amsterdam, the majority of housing is public rental housing. In addition, since the 18th century, public policy aims to mix poor and rich households through construction of different types of housing in the same neighborhood. Other factors also play an important role. For example, the city center of Amsterdam offers many amenities that attract richer people (see Brueckner et al., 1999, and Koster et al., 2014), while provision of good public transport attracts the poor (Glaeser et al., 2008, and LeRoy and Sonstelie, 1983).
} 
TABLE 1 - CAR OWNERSHIP IN AMSTERDAM (PER ADULT CAPITA)

\begin{tabular}{lccccc}
\hline Area & $1986-1991$ & $1994-1997$ & $1998-2000$ & $2001-2004$ & $2005-2008$ \\
\hline Center & 0.31 & 0.32 & 0.32 & 0.31 & 0.31 \\
West & 0.27 & 0.27 & 0.28 & 0.29 & 0.31 \\
East & 0.28 & 0.30 & 0.32 & 0.34 & 0.34 \\
South & 0.35 & 0.38 & 0.41 & 0.42 & 0.43 \\
Amsterdam & 0.32 & 0.33 & 0.35 & 0.36 & 0.37 \\
Netherlands & 0.47 & 0.51 & 0.55 & 0.57 \\
\hline Note: Car ownership is measured as number of cars per capita older than 18 years. Sources: \\
Gemeente Amsterdam (2011) and CBS Statline.
\end{tabular}

income elasticity is in fact higher in urban areas than in rural areas (Dargay, 2002). ${ }^{10}$ As shown in the Appendix, it seems that the income elasticity of car demand is indeed slightly higher in the city center. This implies that a uniform income increase may in fact reduce the differences in car ownership between the city center and the suburbs.

\section{B. Parking policy}

A more plausible explanation for the relative decline of car ownership in the center is the (almost) fixed supply of parking in the historic city center. In the center of Amsterdam, constructing parking garages is extremely expensive, so few residents own private parking spaces and commercial off-street parking is limited (Van Ommeren et al., 2011). Consequently, due to the strong increases in household income witnessed over the last 50 years, demand for residential street parking has strongly increased.

From the beginning of the seventies, Amsterdam has struggled with a parking-intrusion problem, so residents were unable to park in front of their homes because of strong parking demand. To address this increased demand for parking, paid on-street parking for nonresidents was introduced combined with a restrictive residential parking-permit policy. This has led to the introduction of paid-parking districts in 1992 with fairly high visitor parking fees (up to $€ 5$ per hour or $€ 40$ per day in 2015) (Gemeente Amsterdam, 2000). Residential car owners were offered the opportunity to apply for a parking permit, which is only valid in the neighborhood where residents live and which cannot be traded among households.

Permits for residents generally cost between $€ 100$ and $€ 400$ per year. ${ }^{11}$ This is only a fraction of the on-street tariff (about 2.5 percent) and also considerably less than the price in the commercial off-street parking market, which is around $€ 3,600$ per year for a full

\footnotetext{
${ }^{10}$ In contrast, between-country studies suggest that densely-populated countries with good public transport converge to equilibrium states with fewer cars. When ownership is close to its predicted maximum, it becomes rather insensitive to changes in income (Dargay et al., 2007).

${ }^{11}$ In some districts, a permit only costs $€ 24$ per year.
} 


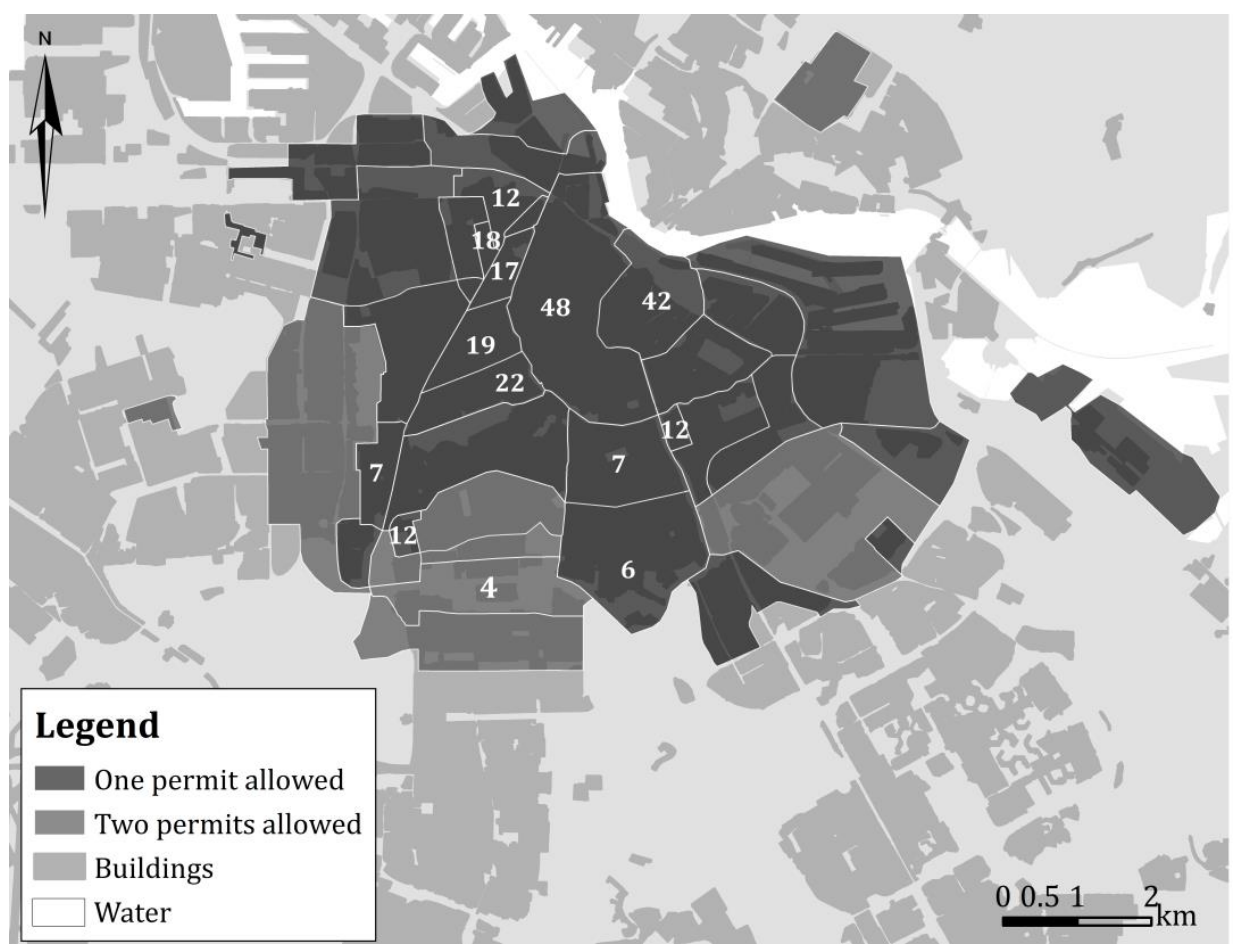

FIGURE 1 -PARKING DISTRICTS IN AMSTERDAM

Note: Numbers refer to waiting-list duration in months in 2010. Source: Cition.

subscription in the center (and between $€ 1,200$ and $€ 2,400$ for a nighttime subscription (see Q-Park, 2014)). A parking permit therefore subsidizes car owners by about $€ 3,200$ per year, which is about half the cost of owning a car net of parking expenses (Nibud, 2015).12

The substantial subsidy has created a strong demand for permits that far exceeds the stock of street parking in many paid-parking districts. Given excess demand for parking permits, the number of parking permits has been limited to one per household or two per household, depending on the district in which the household resides.

In the city center, despite the one permit per household restriction, there is still excess demand for parking permits, which has led the local government to introduce waiting lists for permits. Waiting lists nowadays vary from only a few months for neighborhoods further from the center to about four years in the city center. Households on waiting lists are obliged to live in the district where they are on the waiting list and own a car, implying that these households pay the market price for parking of about $€ 3,600$ per year while they are on the waiting list. This institutional feature is important for our interpretation of the results,

12 In the city center, parking prices can even be as high as $€ 500$ or even $€ 1,000$ per month, or as low as $€ 100$ per month, but these are extreme cases. Van Ommeren et al. (2011) show, based on house prices, that a privately-owned parking space costs about $€ 3,600$ per year, which is indeed very close to the market price. Later on, in the welfare calculations, we will assume that the annual costs of parking are $€ 3,600$. 
because it means that we are able to put a monetary price on the cost of waiting one year longer for a permit.

Figure 1 shows the different parking regimes in Amsterdam. The dark-colored areas refer to the paid-parking districts where only one permit is allowed (the 'one-permit districts') and the lighter areas are the paid-parking districts where two parking permits are allowed ('twopermits districts'). The numbers indicate the waiting-list duration in months in 2010. There are 13 waiting-list districts with varying waiting-list durations. We have accurate information for the waiting-list duration for the year 2010. For 2000, we have a good proxy for the actual waiting-list duration because we know the subscription length of the first person on the waiting list (Gemeente Amsterdam, 2000). In the analysis, where we analyze car ownership between 2004 in 2012, we use the average of the waiting-list duration for the years 2000 and 2010.

\section{Econometric framework and identification}

We aim to estimate the impact of waiting list duration on car ownership. Our identification strategy uses cross-sectional variation and exploits spatial variation in car ownership, which has the advantage that in principle long-run effects are identified. We estimate:

$$
C_{i j t}=\beta D_{j}+\gamma_{1} P_{1 j}+\gamma_{2} P_{2 j}+\delta_{t}+\varepsilon_{i j t}
$$

where $C_{i j t}$ is the number of cars owned by household $i$ in district $j$ in year $t$. In the analysis, we will estimate linear models, because these models are more efficient, easier to interpret and because it is more straightforward to include fixed effects. Nonetheless, we will also estimate a multinomial probit model in the sensitivity analysis (see Table 7). We focus on the effect of waiting-list duration $D_{j}$. With the exception of one area, waiting lists only occur in one-permit districts, so we control for locating either in a one-permit district $P_{1}$ or a twopermits district $P_{2}$, where the reference is a free parking district. We also control for year fixed effects $\delta_{t}$.

The main disadvantage of this specification is that it ignores that most spatial differences in car ownership are likely not due to parking policy, but due to household sorting. For example, households that have a stronger preference for cars may locate outside the city center (Glaeser et al., 2008). Therefore, in the next specification, we control for household characteristics $H_{i j}$, such as household income and household size, and locational factors $L_{j}$, such as population density, distance to the city center and distance to the parking district boundary. This leads to:

$$
C_{i j t}=\beta D_{j}+\gamma_{1} P_{1 j}+\gamma_{2} P_{2 j}+\boldsymbol{H}_{i j} \delta+\boldsymbol{L}_{j} \eta+\delta_{t}+\varepsilon_{i j t}
$$

A major concern here is that it is impossible to control for all household and location factors that are correlated with $D_{j}$, because many factors are unobserved to the econometrician. This may bias the results. In order to disentangle the effect of waiting-list duration from other unobserved factors, such as the accessibility of public transport, the 
presence of shops and sorting of households, we adopt a boundary-discontinuity design (BDD) (see Bayer et al., 2007; Black, 1999).

We include boundary fixed effects to control for unobserved location characteristics and household sorting. This specification is then given by:

$$
C_{i j t}=\beta D_{j}+\gamma_{1} P_{1 j}+\gamma_{2} P_{2 j}+\boldsymbol{H}_{i j} \delta+\theta_{i b}+\delta_{t}+\varepsilon_{i j t},
$$

where $\theta_{i b}$ denotes the boundary fixed effects; i.e., a number of dummy variables that are equal to one if parking-district boundary $b$ is the closest parking-district boundary to household $i$. In this specification, it is not useful to control for location factors $L_{j}$, as we control for spatial heterogeneity by including the boundary fixed effects. We will show in the sensitivity analysis that the results are reasonably robust to the inclusion of location factors.

The key identifying assumption is that unobserved household and location characteristics are absorbed by the boundary fixed effects $\theta_{i b}$. To make this assumption more plausible, one would like to select households that are within a very close vicinity of the boundary (e.g. 25 meters), but this has the disadvantage that the boundary sample becomes extremely small implying large standard errors. In order to obtain a sufficient number of observations, we select observations within a threshold distance $d_{T}$ (which varies from 50 to 200 meters in the empirical analysis, in line with Black, 1999 and Bayer et al., 2007). To further improve on identification we will only include observations in one-permit districts, to avoid the possibility that households in waiting lists just park their cars in an adjacent free parking district with minimal additional time costs of travelling. Hence, the effect of waiting-list duration is estimated based on:

$$
C_{i j t}=\beta D_{j}+\boldsymbol{H}_{i j} \delta+\theta_{i b}+\delta_{t}+\varepsilon_{i j}, \quad \text { if } d_{i b}<\mathrm{d}_{T} \text { and } P_{1}=1,
$$

where $d_{T}$ is the pre-defined threshold distance and $d_{i b}$ refers to the distance to the nearest district boundary.

Again, the identifying assumption is that unobservable household characteristics are (reasonably) continuous at the boundary or are uncorrelated to $D_{j}$. To make this assumption more plausible, we will also estimate models on subsamples of households who live in waiting-list districts and focus on rental housing only. Because the lion's share of rental housing in the city center of Amsterdam is public housing, for which also extensive waiting lists exist, sorting seems to be less of a problem then.

We further note that this identification strategy is unable to capture the causal effects of residing in one-permit districts $P_{1 j}$ or two-permits districts $P_{2 j}$, because households residing in one-permit areas may park their car outside the permit areas. Hence, the effect of residing in permit districts should be continuous over space and cannot properly identified using a BDD. This is not the case for households in waiting-list districts, who live closer to the city center and therefore do not live close to free-parking districts.

Finally, it seems reasonable to argue that, conditional on car ownership, waiting lists do not have any additional effect on kilometers driven. Consequently, a reduction in car 
ownership implies a reduction in car kilometers and the effects of waiting time on car ownership and car kilometers must be comparable. We will therefore repeat the above analysis using car kilometers rather than car ownership as the dependent variable in the sensitivity analysis.

\section{Data and descriptives}

We employ two similar (cross-sectional) datasets with detailed information about household car ownership for the metropolitan area of Amsterdam (the municipality of Amsterdam and surrounding municipalities). For the years 2004 to 2007, the data was collected by WDM, and from 2008 to 2012 by its successor Bisnode. Car ownership is systematically lower in the WDM dataset. In our analysis, we will combine both datasets and include year dummies, which should control for any systematic difference between these datasets.

The data distinguish between zero, one or at least two cars per household. ${ }^{13}$ The location of the household is available at the six-digit zip-code level (PC6). On average, slightly less than twenty properties on the same side of a street share the same six-digit zip code, so the location is precisely determined (its size is about equal to a census block in the US). There is also information about many other household characteristics, such as income, size, etc. The combined dataset contains over 37,000 observations, of which over 28,000 are within the municipal borders of Amsterdam. Table 2 reports descriptive statistics of the variables of interest. $^{14}$

In the first column, the descriptives are shown for the whole metropolitan area. The average distance to the city center is about $5 \mathrm{~km} .15$ The last three columns provide descriptives for three subsamples of households closer to the city center: the Amsterdam municipality, one-permit districts and waiting-list districts. Households in the latter two districts live at 2.4 and $2.3 \mathrm{~km}$ respectively from the city center.

The first row of Table 2 clearly shows that the number of cars per household is strongly decreasing in distance to city center: for example, car ownership is 0.52 in one-permit and waiting-list districts, about 20 percent less than in the Amsterdam municipality where it is about 0.64 . The next rows show that the number of kilometers driven per year also decreases with distance to city center, and that this is due to the reduction in car ownership, as the distance travelled per car is slightly higher in the city center.

The descriptives indicate that there is some spatial heterogeneity in household characteristics within the Amsterdam metropolitan area. For example, average household

\footnotetext{
13 Because having three cars is extremely rare in the Netherlands, the measurement error generated by not observing the exact number of cars is negligible.

14 The survey seems reasonably representative. Car ownership is 0.74 per household, and therefore about 0.38 per adult, which is almost identical to the 0.37 reported in Table 1.

15 The city center is here defined as the Dam Square.
} 


\section{TABLE $2-$ DESCRIPTIVES}

\begin{tabular}{lcccc}
\hline \hline & $\begin{array}{c}\text { Metropolitan } \\
\text { area }\end{array}$ & $\begin{array}{c}\text { Amsterdam } \\
\text { municipality }\end{array}$ & $\begin{array}{c}\text { One-permit } \\
\text { districts }\end{array}$ & $\begin{array}{c}\text { Waiting-list } \\
\text { districts }\end{array}$ \\
\hline Number of cars (car ownership) & 0.735 & 0.641 & 0.512 & 0.520 \\
Car kilometers per year & 10,105 & 9,139 & 7,921 & 8,034 \\
Car kilometers per year per car & 14,330 & 14,785 & 15,885 & 15,904 \\
& & & & \\
Waiting-list duration (in years) & 0.252 & 0.331 & 0.691 & 1.138 \\
Waiting-list district & 0.221 & 0.291 & 0.608 & 1.000 \\
One-permit district (excluding waiting-list districts) & 0.143 & 0.188 & 0.393 & 0.000 \\
Two-permits district (excluding one-permit districts) & 0.092 & 0.121 & 0.000 & 0.000 \\
Free parking district (excluding permit districts) & 0.544 & 0.400 & 0.000 & 0.000 \\
Distance to district boundary (km) & 1.270 & 0.713 & 0.219 & 0.237 \\
& & & & \\
Distance to city center (km) & 5.041 & 4.037 & 2.440 & 2.322 \\
Distance to nearest railway station $(k m)$ & 2.107 & 1.811 & 1.438 & 1.403 \\
Population density (per $k m^{2}$ ) & 9,775 & 11,217 & 16,313 & 16,984 \\
Monthly household income ( $€$ ) & 2,944 & 2,856 & 2,880 & 2,956 \\
Household size & 2.33 & 2.28 & 2.10 & 2.07 \\
Age (average of adults) & 44.6 & 43.5 & 40.9 & 41.4 \\
Number of observations & 37,501 & 28,504 & 13,660 & 8,299 \\
\hline Note: In the columns, the metropolitan area includes the Amsterdam & municipality, the municipality includes one- \\
permit districts and one-permit districts include waiting-list districts. & & &
\end{tabular}

size in waiting-list districts is about 10 percent below the metropolitan average. ${ }^{16}$ As discussed earlier, household income shows no spatial pattern.

The district characteristics distinguish between four mutually-exclusive parking district categories: waiting-list districts, one-permit districts without a waiting list, two-permits districts and parking districts that have no paid parking and therefore no residential permits. ${ }^{17}$ Even at the scale of the metropolitan area, a substantial proportion of households lives in areas with paid parking and therefore parking permits: 22 percent of households resides in a waiting-list district, 14 percent in a one-permit district without waiting lists, and 9 percent in a two-permits district.

The average waiting-list duration is slightly more than one year for households living in a waiting-list district. Waiting lists for residential permits will mainly affect households that aim to increase the car ownership (from zero to one car) and will register on the waiting list. This may either refer to incumbent households (who have lived for a certain period within a waiting-list district) who aim to increase car ownership for example because of changes in the household characteristics (income, children) or to new households (that move into the waiting-list district). Note that incumbent households that have moved into the waiting-list

${ }^{16}$ One explanation is the presence of a large share of public rental housing throughout the city (about 60 percent of all houses in the municipality).

${ }^{17}$ This is not completely accurate. As Figure 1 shows, there is a two-permit district with waiting lists. However, this is a business districts with very few households, so we ignore it in the analysis. 
district before there was a (substantial) waiting list and aimed to increase car ownership were facing lower waiting costs. Consequently, the effect of waiting-time duration will be an underestimate of the long-run effect. Given data on the duration of residence from Statistics Netherlands, it appears that about 12 percent of the households was living in the city center before 1992, when paid parking was introduced. Again, because waiting lists may not have been important at that time, our estimates of the effect of waiting lists on car ownership will be underestimates.

The descriptives indicate that waiting-list districts are very similar to other one-permit districts with respect to location and household characteristics. It will therefore make sense to only focus on one-permit and waiting-list districts in the estimation later on. Note that only about one quarter of households within the municipality of Amsterdam own their house. To control for unobserved household characteristics, we employ a BDD where we include boundary fixed effects. In our data, the average distance for observations in one-permit and waiting-list districts is only slightly above 200 meters.

Table 3 reports car ownership levels again for the municipality of Amsterdam by tabulating the number of cars per household for four mutually-exclusive parking districts. It shows that even in the free-parking district (and therefore no permit provision), the share of households with two or more cars is only 14 percent. Hence, it seems that most households decide on whether or not to have one car. This is particularly true in waiting-list districts and other one-permit districts, where the share of households that have more than two cars is about 5 to 7 percent and where the majority of households decide to have no car.

The provision of parking permits implies a substantial (implicit) subsidy (of about $€ 3,200$ per year) to households with cars. To receive the subsidy the household must relocate to districts that offer these subsidies. It is well known that car ownership strongly increases with household income. Importantly, the positive relationship between car ownership and income holds regardless of the parking district where the households are located (see Figure 2).

TABLE 3 - CAR OWNERSHIP PER DISTRICT

\begin{tabular}{lcccc}
\hline \hline District & Number of cars & 2 or more cars & 1 car & No cars \\
\hline Waiting list & 0.520 & 0.070 & 0.380 & 0.550 \\
One-permit without waiting list & 0.500 & 0.055 & 0.390 & 0.555 \\
Two-permits & 0.694 & 0.103 & 0.488 & 0.409 \\
Free parking & 0.780 & 0.137 & 0.506 & 0.357 \\
Average & 0.641 & 0.098 & 0.445 & 0.457 \\
\hline
\end{tabular}




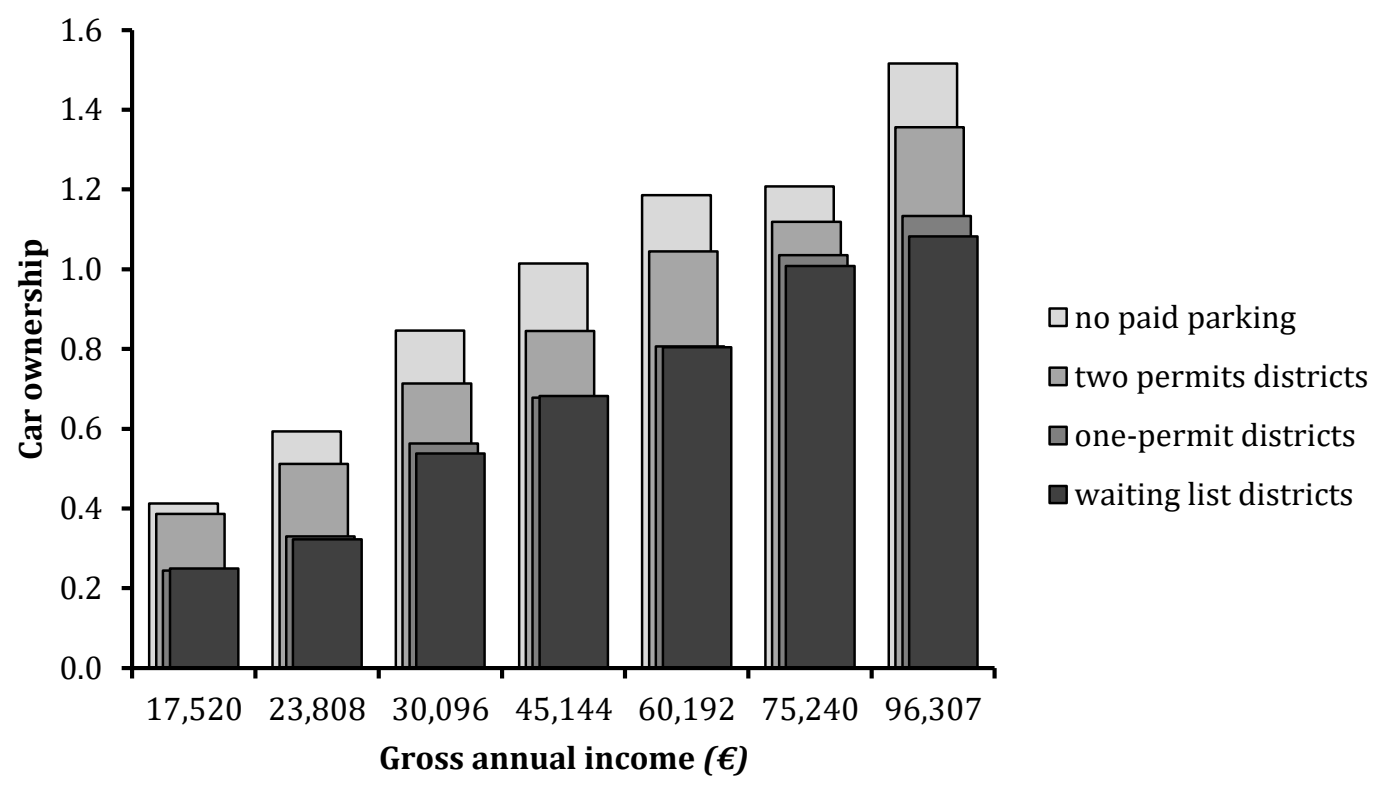

FIGURE 2 - AVERAGE PER-HOUSEHOLD CAR OWNERSHIP AND INCOME Note: The different categories are mutually exclusive.

We distinguish between seven income levels. Gross annual income of the poorest group is about $€ 18,000$ (approximately the minimum wage for a full-time job in the Netherlands) and of the highest-income group is almost $€ 100,000$ (about three times average income). In waiting-list and other one-permit districts, where the implied subsidy is the highest, car ownership of the highest-income group is about four to five times higher than of the poorest group. This indicates that, conditional on residence location, high-income households disproportionately benefit from residential parking-permits schemes. This distributional effect of residential parking subsidies is by no means unique: public-transport subsidies also tend to benefit the higher-income groups disproportionally (see e.g. Frankena, 1973). What is unique, however, is that the subsidy is very substantial, as it is equal to about 18 percent of the poorest group gross annual income, and is income regressive.

\section{Empirical results}

\section{A. Baseline results}

We report the baseline results of the effect of waiting-list duration on car ownership in Table 4. Columns (1) to (3) report results based on equations (1) to (3) using 28,504 observations for households living in the municipality of Amsterdam. We start with an OLS regression without controls, except for the type of parking district, then we add household and location 
TABLE 4 - BASELINE RESULTS: THE EFFECT OF WAITING LIST DURATION ON CAR OWNERSHIP (dependent variable: number of cars)

\begin{tabular}{|c|c|c|c|c|c|c|}
\hline & $(1)$ & $(2)$ & (3) & $(4)$ & $(5)$ & (6) \\
\hline & OLS & OLS & BDD & BDD & BDD & BDD \\
\hline Waiting-list duration & $\begin{array}{c}-0.016^{* *} \\
(0.008)\end{array}$ & $\begin{array}{c}0.003 \\
(0.006)\end{array}$ & $\begin{array}{c}-0.003 \\
(0.007)\end{array}$ & $\begin{array}{c}-0.022^{* *} \\
(0.009)\end{array}$ & $\begin{array}{c}-0.022^{* * *} \\
(0.006)\end{array}$ & $\begin{array}{c}-0.034^{* * * *} \\
(0.004)\end{array}$ \\
\hline One-permit district & $\begin{array}{c}-0.254^{* * *} \\
(0.021)\end{array}$ & $\begin{array}{c}-0.121^{* * *} \\
(0.014)\end{array}$ & $\begin{array}{c}-0.111^{* * *} \\
(0.022)\end{array}$ & & & \\
\hline Two-permits district & $\begin{array}{c}-0.042^{* * *} \\
(0.006)\end{array}$ & $\begin{array}{c}-0.029 * * * \\
(0.008)\end{array}$ & $\begin{array}{c}-0.038^{* * *} \\
(0.009)\end{array}$ & & & \\
\hline Income $(\log )$ & & $\begin{array}{c}0.445^{* * *} \\
(0.009)\end{array}$ & $\begin{array}{c}0.447^{* * *} \\
(0.010)\end{array}$ & $\begin{array}{c}0.456^{* * *} \\
(0.026)\end{array}$ & $\begin{array}{c}0.437^{* * *} \\
(0.031)\end{array}$ & $\begin{array}{c}0.422^{* * *} \\
(0.049)\end{array}$ \\
\hline Household size $(\log )$ & & $\begin{array}{c}0.216^{* * *} \\
(0.008)\end{array}$ & $\begin{array}{c}0.218^{* * *} \\
(0.008)\end{array}$ & $\begin{array}{c}0.219 * * * \\
(0.024)\end{array}$ & $\begin{array}{c}0.214^{* * *} \\
(0.041)\end{array}$ & $\begin{array}{c}0.205^{* * *} \\
(0.051)\end{array}$ \\
\hline Single household & & $\begin{array}{c}-0.086^{* * *} \\
(0.020)\end{array}$ & $\begin{array}{c}-0.085^{* * *} \\
(0.020)\end{array}$ & $\begin{array}{l}-0.028 \\
(0.044)\end{array}$ & $\begin{array}{c}-0.012 \\
(0.070)\end{array}$ & $\begin{array}{c}-0.026 \\
(0.137)\end{array}$ \\
\hline Couple & & $\begin{array}{l}0.027^{* *} \\
(0.011)\end{array}$ & $\begin{array}{c}0.027 \\
(0.011)\end{array}$ & $\begin{array}{l}-0.015 \\
(0.037)\end{array}$ & $\begin{array}{c}0.025 \\
(0.048)\end{array}$ & $\begin{array}{c}-0.003 \\
(0.168)\end{array}$ \\
\hline Family & & $\begin{array}{c}-0.055^{* * *} \\
(0.018)\end{array}$ & $\begin{array}{l}-0.054 \\
(0.018)\end{array}$ & $\begin{array}{c}0.001 \\
(0.039)\end{array}$ & $\begin{array}{c}0.048 \\
(0.058)\end{array}$ & $\begin{array}{c}0.016 \\
(0.187)\end{array}$ \\
\hline Secondary school & & $\begin{array}{c}0.014 \\
(0.024)\end{array}$ & $\begin{array}{c}0.007 \\
(0.026)\end{array}$ & $\begin{array}{l}0.040^{* *} \\
(0.019)\end{array}$ & $\begin{array}{c}0.039 \\
(0.024)\end{array}$ & $\begin{array}{l}0.114^{* *} \\
(0.043)\end{array}$ \\
\hline Vocational education & & $\begin{array}{c}0.032^{* * *} \\
(0.009)\end{array}$ & $\begin{array}{c}0.029 * * * \\
(0.009)\end{array}$ & $\begin{array}{c}0.034 \\
(0.024)\end{array}$ & $\begin{array}{c}0.004 \\
(0.028)\end{array}$ & $\begin{array}{c}0.092^{*} \\
(0.049)\end{array}$ \\
\hline Age & & $\begin{array}{c}0.016^{* * *} \\
(0.002)\end{array}$ & $\begin{array}{c}0.017^{* * *} \\
(0.002)\end{array}$ & $\begin{array}{l}0.009^{* *} \\
(0.004)\end{array}$ & $\begin{array}{l}0.012^{* *} \\
(0.005)\end{array}$ & $\begin{array}{c}0.009 \\
(0.008)\end{array}$ \\
\hline $\operatorname{Age}^{2}(/ 1000)$ & & $\begin{array}{c}-0.142^{* * *} \\
(0.022)\end{array}$ & $\begin{array}{c}-0.149^{* * *} \\
(0.024)\end{array}$ & $\begin{array}{c}-0.058 \\
(0.044)\end{array}$ & $\begin{array}{c}-0.090 \\
(0.062)\end{array}$ & $\begin{array}{c}-0.033 \\
(0.086)\end{array}$ \\
\hline Location characteristics & No & Yes & No & No & No & No \\
\hline Year fixed effects & Yes & Yes & Yes & Yes & Yes & Yes \\
\hline Boundary fixed effects & No & No & Yes & Yes & Yes & Yes \\
\hline One-permit districts only & No & No & No & Yes & Yes & Yes \\
\hline Waiting-lists districts only & No & No & No & No & Yes & No \\
\hline Min waiting-list duration difference (in months) & $\infty$ & $\infty$ & $\infty$ & $\infty$ & $\infty$ & 12 \\
\hline Max distance to boundary (in $\mathrm{m}$ ) & $\infty$ & $\infty$ & $\infty$ & 100 & 100 & 100 \\
\hline Number of observations & 28,504 & 28,504 & 28,504 & 3,565 & 1,988 & 468 \\
\hline$R^{2}$ & 0.046 & 0.245 & 0.247 & 0.232 & 0.255 & 0.272 \\
\hline
\end{tabular}

controls (distance to the city center, distance to the parking district boundary, distance to the railway station, population density). Finally, we add boundary fixed effects. In the latter specification, we do not control for location controls. ${ }^{18}$

${ }^{18}$ In column (2) the estimated effects of the location controls are available upon request. If we also control for location characteristics in (3), the results are virtually unchanged. 


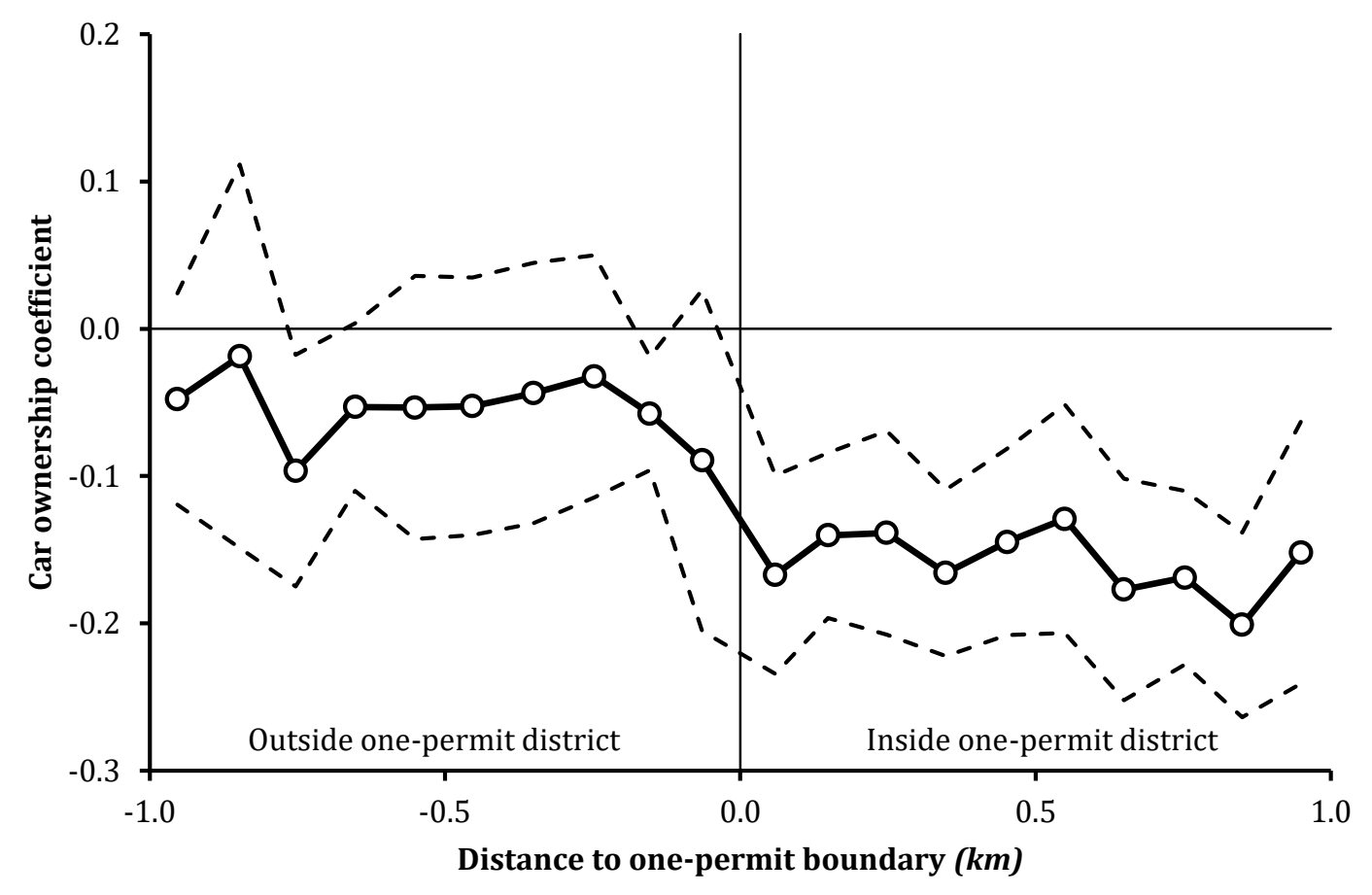

FIGURE 3 - CAR OWNERSHIP COEFFICIENT AROUND ONE-PERMIT BOUNDARIES

Note: The car ownership coefficient is estimated as in column (3) when the one-permit district variable is replaced by multiple dummy variables. The dotted lines indicate the 95-percent confidence interval.

In column (1) the coefficient with respect to the length of the waiting list is negative. The effect of waiting-list duration on car ownership is equal to -0.016 , so one year increase in the waiting list leads to a decrease in car ownership of 1.6 percentage points. The effect becomes statistically insignificant if we include household and location characteristics in column (2) and boundary fixed effects in column (3). In these specifications, the effect of locating in a one-permit district is strongly negative, which is only suggestive evidence that one-permit restrictions strongly reduce car ownership because households that live close to a district with free parking may park in the latter district. Hence, we cannot exclude the possibility that the effect is at least partially explained by sorting on household unobservables. If this is the case, we may expect a continuous rather than discrete change of car ownership over space. We test this in Figure 3, in which we re-estimate the specification in column (2) but replace the one-permit district dummy by $100 \mathrm{~m}$ distance band dummies. Hence, Figure 3 depicts the coefficients of $100 \mathrm{~m}$ distance band dummies. It appears that car ownership decreases rather strongly around the one-permit boundary, but without a noticeable discrete jump at the boundary. Hence, this effect might not only be explained by parking policies, but also be explained by household sorting along the parking district 
boundaries and by the fact that people may park their (second) car in a free-parking district and walk to their homes.

In the next specifications, we therefore only focus on one-permit districts, because it is not allowed to park a car in another district than the district for which a permit is granted. This allows us to more accurately estimate the effect of waiting-list duration between districts with and without waiting lists for parking permits. In column (4) of Table 4 we select observations within 100 meters of the nearest parking-district boundary. Although the selected sample refers to only 12.5 percent of the observations in the full sample, the standard error of the waiting-list effect does not increase substantially, implying that the main disadvantage of selecting samples close to the boundary - a strong decrease in efficiency of the estimates - hardly applies here. We now find that the negative effect of waiting-list duration is much more substantial (and statistically significant at conventional significance levels). As discussed above, the boundary-discontinuity set-up is more likely to lead to consistent estimates and is therefore preferred over the OLS estimates. The results appear somewhat sensitive to the choice in area size, but we come back to this issue in the sensitivity analysis.

Column (5) reports the results where we only focus on households in waiting-list districts, so the effect is identified based on districts with a positive waiting-list duration. The point estimate of waiting-list duration remains unchanged compared to the reported effect in column (4). ${ }^{19}$ In column (6) we focus on locations near boundaries of districts with a large (over a year) difference in waiting-list duration. Similar to Bayer et al. (2007), we then identify the coefficient on differences that are economically meaningful. More importantly, the larger differences are less likely to be subject to measurement error. For the areas with long waiting lists, we know that these areas also had long waiting lists in 2000. For other areas, due to some changes in district boundaries, it is more difficult to determine the average waiting-list duration across the sample period. We again find that the effect of waiting-list duration is negative and the point estimate of -0.034 is somewhat stronger compared to the previous estimates, which suggests that measurement error is less of a problem here, as this would lead to a bias towards zero. However, in the analysis, we will use the more conservative estimate of -0.022 of column (4) and (5).

It is useful to express these results in terms of price elasticities of demand. According to our preferred specifications, waiting lists reduce car ownership by about 2 percentage points per year. As the average car ownership level in the waiting-list district is 0.50 , this corresponds to a 4 percent decrease in car ownership, which implies that the price elasticity of demand is about $-0.8 .^{20}$ The demand for cars appears considerably more elastic than the

${ }^{19}$ Note furthermore that the standard error of the effect is reduced, which may be explained by the fact that households who live in districts with a positive waiting-list duration are more similar to each other.

${ }^{20}$ As calculated in the welfare analysis section, a year on the waiting list increases car user costs by about 5 percent, so the elasticity is $\varepsilon \approx-0.04 / 0.05 \approx-0.8$. 
average values reported in the literature. Arguably, our finding of a more price elastic demand in the center of Amsterdam is plausible because of the availability of close substitutes for the car, in particular public transport and the bicycle, which is likely to increase this elasticity.

We find that the estimated effect of the logarithm of income on car ownership is robust with respect to specification and is between 0.42 and 0.46 . The implied income elasticity of car ownership is then about 0.7 (obtained by dividing the estimated effect of the logarithm of income by the average car ownership in our data, which is 0.64). ${ }^{21}$ In the Appendix we show that cars are a generally a normal good and can only be considered as a luxury good for lowincome households. In general, car demand of households residing in one-permit districts is slightly more income elastic.

\section{B. Sensitivity analysis}

The results above indicate that the effect of waiting-list duration on car ownership is generally negative once we select samples closer to the parking boundary, with point estimates between 0.003 and -0.034 , while our preferred estimates are -0.022 . In this subsection, we will perform a range of robustness checks.

First, we examine whether our results are sensitive with respect to excluding important control variables and to focus on rental housing only. If excluding important observable household and location characteristics will not lead to substantially different results, this might indicate that unobservable household characteristics are also not very important in explaining the effect of waiting lists on car ownership. Therefore, to investigate the sensitivity of our results with respect to important controls, we exclude all household characteristics in columns (1)-(3) in Table 5. It is shown that the effect of waiting-list duration becomes somewhat stronger (up to twice as large). However, because unobservable household characteristics are likely strongly correlated to observable household characteristics it will be unlikely that the effect of waiting lists on car ownership can be fully explained by sorting. In the second set of specifications in Table 5 (columns (4)-(6)) we include the location characteristics. The effect of waiting-list duration appears stronger than in the baseline specification. Hence, controlling for, arguably the most important (unobserved) amenities amplifies the effect, so our initial estimates may be underestimates.

One might still be worried that sorting is the main explanation for the negative effect of waiting lists on car ownership. We therefore also estimate specifications where we only focus on households occupying rental housing. There are two fundamental reasons to only focus on these households. First, the majority of the Amsterdam rental housing market is public housing (and rent-controlled), which is allocated based on public housing waiting lists, with waiting durations of minimally 15 years in the city center. The allocation process of public

${ }^{21}$ This elasticity is close to the elasticity of 0.61 found by Clark (2007) for the UK. 
TABLE 5 - SENSITIVITY ANALYSIS: HOUSEHOLD AND LOCATION CHARACTERISTICS (dependent variable: number of cars)

\begin{tabular}{|c|c|c|c|c|c|c|c|c|c|}
\hline & \multicolumn{3}{|c|}{ Exclude all household characteristics } & \multicolumn{3}{|c|}{ Include location characteristics } & \multicolumn{3}{|c|}{ Only rental housing } \\
\hline & $(1)$ & $(2)$ & $(3)$ & $(4)$ & $(5)$ & $(6)$ & $(7)$ & $(8)$ & $(9)$ \\
\hline & BDD & BDD & BDD & BDD & BDD & BDD & & & \\
\hline Waiting-list duration & $\begin{array}{c}-0.048^{* * *} \\
(0.008)\end{array}$ & $\begin{array}{c}-0.040^{* * *} \\
(0.016)\end{array}$ & $\begin{array}{c}-0.060^{* * *} \\
(0.007)\end{array}$ & $\begin{array}{c}-0.033^{* *} \\
(0.016)\end{array}$ & $\begin{array}{c}-0.057^{* * *} \\
(0.016)\end{array}$ & $\begin{array}{c}-0.072^{* * *} \\
(0.017)\end{array}$ & $\begin{array}{c}-0.038^{* * *} \\
(0.013)\end{array}$ & $\begin{array}{c}-0.060^{* * *} \\
(0.011)\end{array}$ & $\begin{array}{c}-0.045^{* * *} \\
(0.018)\end{array}$ \\
\hline Waiting-list duration $\times$ share of public housing & & & & & & & $\begin{array}{c}0.003 \\
(0.015)\end{array}$ & $\begin{array}{c}0.012 \\
(0.029)\end{array}$ & $\begin{array}{c}-0.019 \\
(0.016)\end{array}$ \\
\hline Household characteristics & No & No & No & Yes & Yes & Yes & Yes & Yes & Yes \\
\hline Location characteristics & No & No & No & Yes & Yes & Yes & No & No & No \\
\hline Year fixed effects & Yes & Yes & Yes & Yes & Yes & Yes & Yes & Yes & Yes \\
\hline Boundary fixed effects & Yes & Yes & Yes & Yes & Yes & Yes & Yes & Yes & Yes \\
\hline One-permit districts only & Yes & Yes & Yes & Yes & Yes & Yes & Yes & Yes & Yes \\
\hline Waiting-lists districts only & No & Yes & No & No & Yes & No & No & Yes & No \\
\hline Min waiting-list duration difference (in months) & $\infty$ & $\infty$ & 12 & $\infty$ & $\infty$ & 12 & $\infty$ & $\infty$ & 12 \\
\hline Max distance to boundary (in $\mathrm{m}$ ) & 100 & 100 & 100 & 100 & 100 & 100 & 100 & 100 & 100 \\
\hline Number of observations & 3,565 & 1,988 & 468 & 3,565 & 1,988 & 468 & 2,655 & 1,466 & 339 \\
\hline$R^{2}$ & 0.043 & 0.071 & 0.074 & 0.234 & 0.259 & 0.285 & 0.167 & 0.194 & 0.239 \\
\hline
\end{tabular}

Note: Standard errors are in parenthesis and clustered at the parking-district level. The reference household is a multi-person household with university degree. education level. The asterisks indicate significance levels. ${ }^{* * *} \mathrm{p}<0.01,{ }^{* *} \mathrm{p}<0.05,{ }^{*} \mathrm{p}<0.1$. 
TABLE 6 - SENSITIVITY ANALYSIS: DISTANCE TO THE BOUNDARY (dependent variable: number of cars)

\begin{tabular}{|c|c|c|c|c|c|c|}
\hline & \multicolumn{3}{|c|}{ Within 200 meters of a boundary } & \multicolumn{3}{|c|}{ Within 50 meters of boundary } \\
\hline & (1) & (2) & (3) & (4) & (5) & (6) \\
\hline & BDD & BDD & BDD & BDD & BDD & BDD \\
\hline Waiting-list duration & $\begin{array}{c}-0.004 \\
(0.009)\end{array}$ & $\begin{array}{c}-0.015^{* *} \\
(0.006)\end{array}$ & $\begin{array}{c}-0.019^{* * *} \\
(0.005)\end{array}$ & $\begin{array}{c}-0.047^{* *} \\
(0.019)\end{array}$ & $\begin{array}{c}-0.034 \\
(0.022)\end{array}$ & $\begin{array}{c}-0.058^{* * *} \\
(0.019)\end{array}$ \\
\hline Household characteristics & Yes & Yes & Yes & Yes & Yes & Yes \\
\hline Year fixed effects & Yes & Yes & Yes & Yes & Yes & Yes \\
\hline Boundary fixed effects & Yes & Yes & Yes & Yes & Yes & Yes \\
\hline One-permit districts only & Yes & Yes & Yes & Yes & Yes & Yes \\
\hline Waiting-lists districts only & No & Yes & No & No & Yes & No \\
\hline Min waiting-list duration difference (in months) & $\infty$ & $\infty$ & 12 & $\infty$ & $\infty$ & 12 \\
\hline Max distance to boundary (in $\mathrm{m}$ ) & 200 & 200 & 200 & 50 & 50 & 50 \\
\hline Number of observations & 7,650 & 4,317 & 972 & 1,321 & 741 & 164 \\
\hline$R^{2}$ & 0.222 & 0.242 & 0.248 & 0.245 & 0.298 & 0.384 \\
\hline
\end{tabular}

Note: Standard errors are in parenthesis and clustered at the parking-district level. Note that in specification (2), we also control for distance to the district boundary, distance to the city center, distance to the nearest railway station and population density. The reference household is a multi-person household with university degree. education level. The asterisks indicate significance levels. ${ }^{* * *} \mathrm{p}<0.01,{ }^{* *} \mathrm{p}<0.05,{ }^{*} \mathrm{p}<0.1$.

housing makes it rather difficult for households to sort exactly across the parking district boundary. Hence, by focusing on rental housing, the potential econometric problem of sorting based on unobserved household characteristics is mitigated. Note, however, that public houses are occupied by low-income households, which may be less sensitive to waiting lists for parking permits. Second, private rental houses are occupied by households for whom the expected residence time is substantially lower than for owners. For these renting households, the implied benefits associated with waiting are small or even zero, in particular when the parking permit waiting duration exceeds the expected residents' duration. It is then more likely that waiting list duration will have a more pronounced effect on car ownership. In our data, it is unknown whether a rental house is a public house, but we have access to the share of public housing in the six-digit zip-code area (which contains on average 12 houses). For the majority of observations, the share is either zero or one, so the share is a reasonable indicator of public housing without too much measurement error.

For households that live in rental housing, we estimate the same models as above, however we interact the waiting-list duration with the share of public housing in the six-digit zip-code area. It appears that car ownership of rental households is more sensitive to waiting-list duration, with negative effects of about -0.04 . This confirms the hypothesis that because residents' durations are lower for rental housing, the effect is more pronounced. We also observe that the interaction term with public housing is essentially zero. As sorting along the boundary is much more difficult for households that are eligible for public housing, 
this provides evidence that sorting on unobservable household characteristics along the boundary is unlikely to be a main explanation of the results.

In Table 6 we check robustness of the results with respect to the distance to the boundary threshold, as the assumption on the boundary threshold is somewhat arbitrary. Columns (1) to (3) show results when we select observations within 200 meters of a parking district boundary. The results show that the effect of waiting-list duration has a tendency to become smaller when the chosen area is larger and is not statistically significantly different from zero in column (1). However, when we focus on observations only within 50 meters of a parking district boundary, the effects become stronger. All specifications listed in columns (4)-(6) show that the point estimates are larger in magnitude than the baseline specifications. However, because of the low number of observations, the results are much less precise. Nevertheless, it is reassuring that if we focus on observations closer to parking district boundaries the results become stronger.

In columns (1) to (3) in Table 7 we let the waiting-list duration effect vary for households with a below-average income and above-average income. It is shown that above-average income households tend to react stronger to longer waiting-list durations by reducing car ownership. $^{22}$ The main explanation for this finding is likely that car ownership levels for these households are much higher than for below-average income households 0.81 versus 0.39 in the city center). Hence, households are more sensitive to the duration of waiting when their incomes increase. In Panel B, we provide the implied price elasticities. It appears that the implied price elasticity for above-average income is robust over different specifications and slightly more negative than -1 , while it is not very robust for belowaverage income households.

Columns (4)-(6) in Table 7 report the results of a multinomial probit model, which distinguishes between three categories: zero cars, one car and (at least) two cars. We provide three specifications and report the average total marginal effect of waiting-list duration on car ownership, for ease of comparability with the baseline estimates. Let us define $\beta_{1}$ as the marginal effect of an additional year of waiting on the change in probability of owning one car and $\beta_{2}$ on the change in probability of owning two cars. Hence:

$$
\begin{aligned}
& \beta_{1}=\mathcal{P}\left(\bar{D}_{j}+1, C=1\right)-\mathcal{P}\left(\bar{D}_{j}, C=1\right) \\
& \beta_{2}=\mathcal{P}\left(\bar{D}_{j}+1, C=2\right)-\mathcal{P}\left(\bar{D}_{j}, C=2\right)
\end{aligned}
$$

where $\mathcal{P}(\cdot)$ denotes the probability. So the overall change in car ownership is then:

$$
\mathbb{E}\left(C_{i j} \mid \bar{D}_{j}+1, P_{1}, P_{2}, H_{i j}, \delta_{t}\right)-\mathbb{E}\left(C_{i j} \mid \bar{D}_{j}, P_{1}, P_{2}, H_{i j}, \delta_{t}\right)=\hat{\beta}_{1}+2 \hat{\beta}_{2}
$$

We evaluate this marginal effect at the mean values of the sample. To calculate the

${ }^{22}$ We have also estimated these regressions for seven income groups leading to similar results. 
TABLE 7 - SENSITIVITY ANALYSIS: INCOME-SPECIFIC EFFECTS, CAR KILOMETERS AND MULTINOMIAL PROBIT: MARGINAL EFFECTS

\begin{tabular}{|c|c|c|c|c|c|c|c|c|c|}
\hline \multirow[b]{3}{*}{ Panel A: Regression results } & \multicolumn{3}{|c|}{ Income-specific effects } & \multicolumn{3}{|c|}{ Multinomial probit (average effect) } & \multicolumn{3}{|c|}{ Car kilometers } \\
\hline & $(1)$ & $(2)$ & $(3)$ & $(4)$ & $(5)$ & (6) & $(7)$ & $(8)$ & (9) \\
\hline & & & & & & & BDD & BDD & BDD \\
\hline Waiting-list duration & & & & $\begin{array}{c}-0.040^{* * *} \\
(0.005)\end{array}$ & $\begin{array}{c}-0.044^{* * *} \\
(0.006)\end{array}$ & $\begin{array}{c}-0.040^{* * *} \\
(0.009)\end{array}$ & $\begin{array}{c}-392.9 * * \\
(187.1)\end{array}$ & $\begin{array}{c}59.0 \\
(86.1)\end{array}$ & $\begin{array}{c}-473.1^{* *} \\
(182.9)\end{array}$ \\
\hline Waiting-list duration $\times$ income below average & $\begin{array}{l}-0.011 \\
(0.012)\end{array}$ & $\begin{array}{l}-0.006 \\
(0.009)\end{array}$ & $\begin{array}{c}-0.025^{* * *} \\
(0.008)\end{array}$ & & & & & & \\
\hline Waiting-list duration $\times$ income above average & $\begin{array}{c}-0.046^{* * *} \\
(0.007)\end{array}$ & $\begin{array}{c}-0.050^{* * *} \\
(0.014)\end{array}$ & $\begin{array}{c}-0.051^{* * *} \\
(0.009)\end{array}$ & & & & & & \\
\hline Household characteristics & Yes & Yes & Yes & Yes & Yes & Yes & Yes & Yes & Yes \\
\hline Location characteristics & No & No & No & Yes & Yes & Yes & No & No & No \\
\hline Year fixed effects & Yes & Yes & Yes & Yes & Yes & Yes & Yes & Yes & Yes \\
\hline Boundary fixed effects & Yes & Yes & Yes & No & No & No & Yes & Yes & Yes \\
\hline One-permit districts only & Yes & Yes & Yes & Yes & Yes & Yes & Yes & Yes & Yes \\
\hline Waiting-lists districts only & No & Yes & No & No & Yes & No & No & Yes & No \\
\hline Min waiting-list duration difference (in months) & $\infty$ & $\infty$ & 12 & $\infty$ & $\infty$ & 12 & $\infty$ & $\infty$ & 12 \\
\hline Max distance to boundary (in $m$ ) & 100 & 100 & 100 & 100 & 100 & 100 & 100 & 100 & 100 \\
\hline Number of observations & 3,565 & 1,988 & 468 & 3,565 & 1,988 & 468 & 3,565 & 1,988 & 468 \\
\hline$R^{2}$ & 0.232 & 0.257 & 0.273 & & & & 0.220 & 0.240 & 0.257 \\
\hline Log-likelihood & & & & $-11,235$ & -6295 & -1465 & & & \\
\hline \multicolumn{10}{|l|}{ Panel B: Implied price elasticities } \\
\hline Income below average & -0.51 & -0.46 & $-1.44^{* * *}$ & & & & & & \\
\hline Income above average & $-1.09^{* * *}$ & $-1.14^{* * *}$ & $-1.16^{* * *}$ & & & & & & \\
\hline
\end{tabular}


standard errors of (6), we use bootstrapped standard errors, clustered at the parking district level. Because the models do not converge once we include parking district boundary fixed effects, we report results without fixed effects. The results should therefore be interpreted with some caution. In column (4) of Table 7 the average marginal effect of an increase in waiting list duration of one year on car ownership is -0.040 percentage points, which is somewhat higher compared to the baseline specification. Columns (5) show that this effect is similar once we focus on areas with some waiting lists. In column (6), we only include observations close to boundaries with waiting list differences of over a year, also leading to similar results. In general, our results therefore seem to be robust to the choice between multinomial probit and linear models.

Until now, we have focused on car ownership. As a sensitivity check, it is useful to examine the effect of waiting lists on (annual) car kilometers. Thus, we will repeat our baseline analysis (as reported in columns (4)-(6) in Table 4) with annual car kilometers as a dependent variable. We emphasize that our measure is a noisy variable, because it is measured in five broad classes, rather than being a continuous variable. Furthermore, car kilometers are self-reported by households, and therefore likely subject to strong measurement error. Columns (7)-(9) in Table 7 report the results. The reported effect in column (7) indicates that one year of waiting for a permit reduces annual car distance by about 393 kilometers (almost 4 percent of the average distance travelled in the city center). Hence, estimates based on car ownership and car kilometers suggest similar effects of waiting lists. The car distance results are however not robust to specification as we find a statistically insignificant (and even positive) estimate in column (8) where we select households in waiting-lists districts. On the other hand, in column (9), where we select households in neighborhoods with large differences in waiting-list duration, an increase in the waiting list of a year leads to a decrease of 473 car kilometers.

\section{Parking policy and welfare}

The provision of residential parking permits yields a deadweight loss if the price of the permit is less than the marginal costs of parking (the costs of providing and maintaining parking space). We have estimated the effect of waiting lists on car ownership, which is useful because waiting lists imply that households incur parking costs equal to the market price while they are on the waiting list. We first focus on the welfare effect of a residential permit in one-permit districts where there is no waiting list. We assume that the marginal costs of parking are equal to the street market price, as paid by nonresidents as well as households that do not own a permit. So, we derive the deadweight loss under the assumption that all externalities due to car ownership and driving the car are internalized through optimal street parking prices. This includes the possibility that parking prices are used as a second-best solution to reduce traffic congestion, as suggested by Glazer and Niskanen (1992) and Verhoef et al. (1995). 
We focus on prices of owning a car $P$, and number of cars $Q$. We emphasize that the price of owning a car includes the price of parking a car. The deadweight loss of the residential parking permit policy depends on the price for permit holders $P_{P}$, the price for no-permit holders $P_{N P}$, car ownership levels given parking permits $Q_{P}$, and car ownership levels without these permits $Q_{N P}$. In the current market equilibrium observed for Amsterdam, (nearly) every car owner possesses a parking permit, so $P=P_{P}$ and $Q=Q_{P}$.

We write the deadweight loss of the parking permits policy $\Delta W$, as the integrated difference between the inverse supply and demand function:

$$
\Delta W=\int_{Q_{N P}}^{Q_{P}}(S(Q)-P(Q)) \mathrm{d} Q
$$

We assume a constant-elasticity inverse demand curve $D(Q)$. This function can be written as $D(Q)=P_{P}\left(Q / Q_{P}\right)^{1 / \varepsilon}$, where $\varepsilon$ is the price elasticity of car demand, which has been estimated above. We assume that the cost of owning a car net of parking cost is exogenous and equal to $P_{0}$.

In order to derive the welfare effects of parking permits, we also need information on the car supply function $S(Q)$. We do not have information about the latter, so we derive the welfare loss based on different assumptions with respect to the car supply function Given the assumption that parking supply is fully elastic, $S(Q)=P_{N P}$ equation (7) can be rewritten as:

$$
\Delta W=\int_{Q_{N P}}^{Q_{P}} P_{N P} d Q-\int_{Q_{N P}}^{Q_{P}} P_{P}\left(\frac{Q}{Q_{P}}\right)^{\frac{1}{\varepsilon}} \mathrm{d} Q .
$$

Parking supply is unlikely to be fully elastic. For example, a recent study by Van Ommeren et al. (2014) for the Netherlands suggests that this elasticity is around one. Given a unit elasticity, the car supply function can be written as: $S(Q)=P_{0}+\left(P_{N P}-P_{0}\right)\left(Q / Q_{N P}\right)$. Equation (7) can then be written as:

$$
\Delta W=\int_{Q_{N P}}^{Q_{P}} P_{0}+\left(P_{N P}-P_{0}\right)\left(\frac{Q}{Q_{N P}}\right) \mathrm{d} Q-\int_{Q_{N P}}^{Q_{P}} P_{P}\left(\frac{Q}{Q_{P}}\right)^{\frac{1}{\varepsilon}} \mathrm{d} Q .
$$

Figure 4 shows the deadweight loss in case of unitary elastic supply. We assume that the annual price of owning a car excluding parking costs, denoted by $P_{0}$, is equal to $€ 6,000$ (Nibud, 2015). The price of a parking permit is (maximally) $€ 400$, so $P_{P}$ equals $€ 6,400$. The market price of parking a car is about $€ 3,600$ per year so $P_{N P}$ equals $€ 9,600$. Consequently, a parking permit implies an annual subsidy of approximately $€ 3,200$.

We will now estimate the welfare effects in case of positive waiting-list durations. We are interested in the economic value of the permit to the household given that the household has to wait a number of years in order to get the permit. One complication is that the value of a 


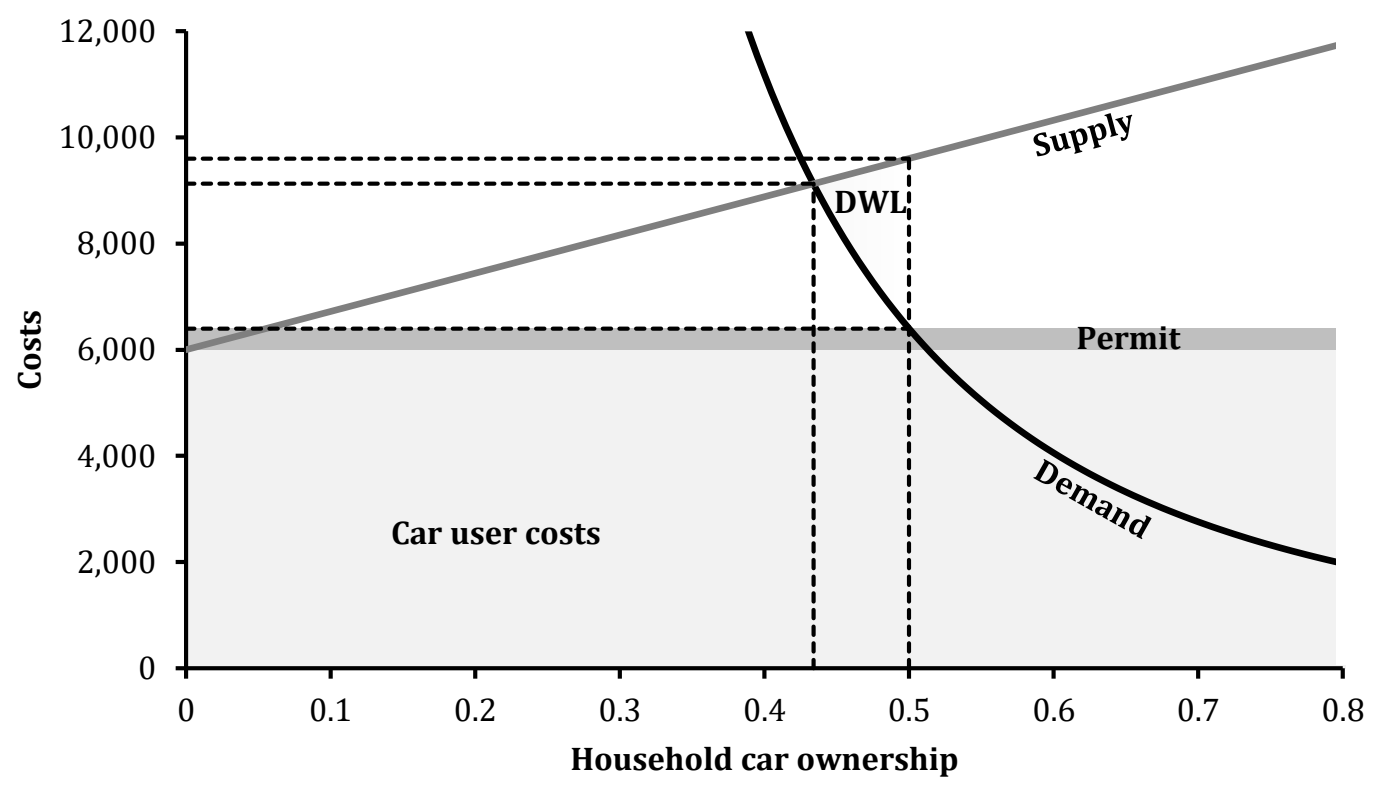

FIGURE 4 - DEADWEIGHT LOSS (DWL) OF PARKING PERMITS

TABLE $8-$ WELFARE EFFECTS PER PERMIT PER YEAR

\begin{tabular}{lcc}
\hline \hline & \multicolumn{2}{c}{ Price elasticity } \\
\cline { 2 - 3 } & -0.65 & -1.00 \\
\hline Unit elastic supply & $-€ 330$ & $-€ 440$ \\
Fully elastic supply & $-€ 400$ & $-€ 600$ \\
\hline
\end{tabular}

permit for a household who waits for a parking permit depends on the expected time that the parking permit will be used and the discount rate at which the future will be discounted. The average elapsed residence duration is 7.9 years in the city center (see Bureau Onderzoek en Statistiek, 2013). This implies that the total duration is two times longer. This is in line with the fact that the average resident has a seven percent chance to move to another city each year, implying the average (median) residence time is about 15 (10) years (see Denktank Markt en Overheid, 2011). Given a discount rate of 4 percent, the net present value of the additional car user costs is about 5 percent per year of waiting-list duration.

Table 8 reports the deadweight losses for a parking permit for which one does not have to wait given different assumptions on the price elasticity of demand and the supply elasticity. Our most conservative estimate of the deadweight loss is $€ 330$, based on a unit elastic supply and a price elasticity of demand of -0.65 . However, the annual deadweight loss may be as high as $€ 600$ given a situation with a fully elastic supply and a price elasticity of 


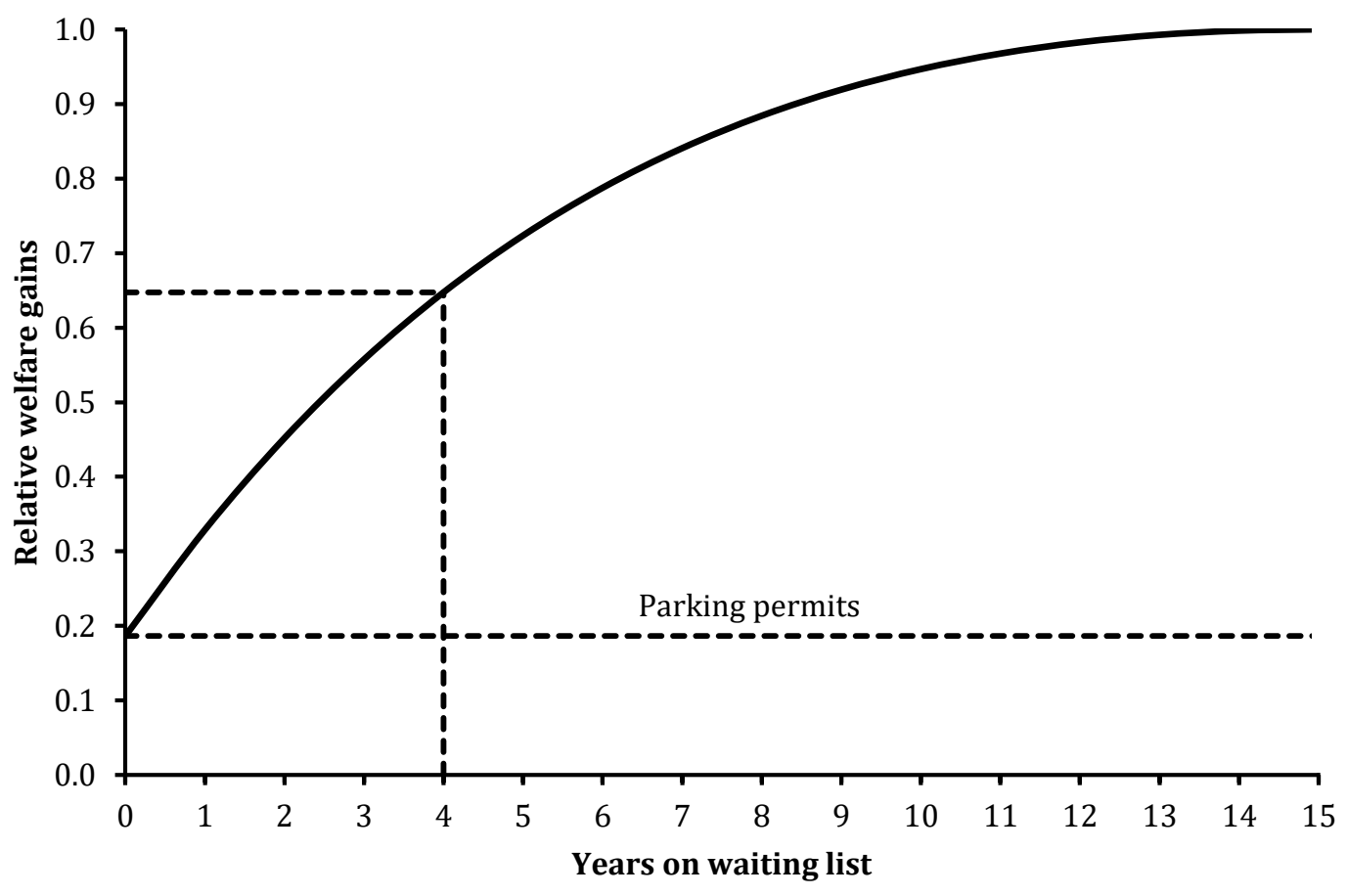

FIGURE 5 - RELATIVE WELFARE GAINS OF PARKING PERMITS AND WAITING LISTS

demand of -1.00. One straightforward exercise is to calculate the social gain of charging a fee for providing parking permits. In Amsterdam, by charging $€ 400$ for the parking permit (the maximum tariff nowadays) rather than providing the permit almost for free, it appears that the welfare loss is reduced by almost 20 percent.

The presence of a waiting list reduces the deadweight losses of parking permits, as a waiting list increases the price of parking towards the market price, which reduces the deadweight loss. Only an 'infinite' waiting list yields no deadweight loss, as residents are then forced to continuously pay the market price for parking. Figure 5 shows the relative lower bound) welfare gains of the length of the waiting-list (given an unit elastic supply and a price elasticity of demand of -0.65). For example, a four-year waiting list (the maximum length in Amsterdam during the study period) reduces the annual welfare loss per permit to about $€ 140$. The average waiting list is slightly more than one year, so the average deadweight loss in the waiting-list area is about $€ 270$. Given 13,000 parking permits in this area (Gemeente Amsterdam, 2000), the annual deadweight loss of parking permits is $€ 3.5$ million in this area alone. We have seen in Table 7 that the price elasticity tends to be higher for households with higher household incomes, which implies that especially high-income households contribute to this welfare loss. 
It is interesting to compare this estimate to the welfare loss of parking permit provision estimated by Van Ommeren et al. (2014). In this study, parking supply elasticities have been estimated in 275 main shopping areas in the Netherlands. These shopping areas are almost always mixed in the sense that they contain many shops as well as housing. Their estimates imply that through the provision of residential parking permits, nonresidents have to pay higher prices for parking as nonresidents are forced to use commercial off-street parking, which is more costly. Given demand elasticities for parking by nonresidents - which are not estimated but are assumed - it appears that their estimates of the welfare losses of parking provision are almost identical to the losses indicated in the current study.

\section{Conclusion}

Very little is known about the effect of parking policy on car ownership, which is a relevant issue because in many cities around the world residential parking is strongly subsidized, so levels of car ownership are likely above welfare-optimal levels. It is plausible that the welfare loss of these subsidies is particularly substantial in city centers where the cost of parking is high and where car demand price elasticities may also be higher.

In the current paper, we aim to estimate the welfare implications of these residential parking subsidies through changes in car ownership. In particular, we analyze the welfare effects of a policy that provides parking permits to residents in Amsterdam. We focus on waiting-list districts, where households may receive maximally one permit after a waiting period that varies between districts (up to four years). In order to be registered on a waitinglist, households are obliged to own a car forcing them to pay the full price of parking while waiting. Our identification strategy exploits spatial variation in the waiting time for parking permits.

We demonstrate that car ownership is lower within parking districts with longer waiting durations. Households react to the (implicit) price increase of waiting longer by reducing car ownership: every year of waiting-list duration decreases car ownership by about 2 percentage points, which implies an (implicit) price elasticity of car demand of about -0.8 . The sensitivity checks indicate that this is likely an underestimate, as the results tend to get stronger the more we try to control for household sorting.

Longer waiting lists for parking permits increase the residential parking price to a level that is closer to the full market price, so longer waiting lists reduce the deadweight loss induced by providing parking permits. Our results indicate that a parking permit scheme strongly decreases welfare. A parking permit, with an average waiting duration of one year, induces an annual welfare loss is $€ 270$, or about $€ 3.5$ million in the city center alone. Such a high welfare loss is plausible given that the implied annual subsidy is about $€ 3,200$ per parking permit.

According to our estimates, increasing the fee for residential parking permits strongly reduces the welfare loss. For example, a fee of only $€ 400$ per year (about 12 percent of the market price of parking) reduces the deadweight loss by almost 20 percent. Alternatively, by 
limiting the provision of parking permits that distort the market and thereby creating waiting lists, local governments may substantially reduce the deadweight loss. For example, a waiting duration of four years reduces the deadweight loss by about 65 percent although the welfare loss is still at least $€ 140$ per permit.

We further show that the subsidy of residential parking associated with the provision of parking permits is mainly beneficial to high-income households, as car demand is very income elastic. This implies that a residential parking subsidy policy is not only distortionary, it is also income-regressive and the welfare loss induced is mainly due to overconsumption of cars by high-income households.

\section{References}

Arnott, R., and Inci, E. (2006). An integrated model of downtown parking and traffic congestion. Journal of Urban Economics, 60(3), 418-442.

Arnott, R., and Rowse, J. (1999). Modeling Parking. Journal of Urban Economics, 45(1), 97-124.

Arnott, R., and Rowse, J. (2009). Downtown parking in auto city. Regional Science and Urban Economics, 39(1), 1-14.

Arnott, R., and Rowse, J. (2013). Curbside parking time limits. Transportation Research Part A: Policy and Practice, 55, 89-110.

Bayer, P., Ferreira, F., and McMillan, R. (2007). A Unified Framework for Measuring Preferences for Schools and Neighborhoods. Journal of Political Economy. 115(4), 588-638.

Black, S. E. (1999). Do Better Schools Matter? Parental Valuation of Elementary Education. Quarterly Journal of Economics, 114(2), 577-599.

Brueckner, J. K., Thisse, J. F., and Zenou, Y. (1999). Why is central Paris rich and downtown Detroit poor? An amenity-based theory. European Economic Review, 43(1), 91-107.

Bureau Onderzoek en Statistiek. (2007). Inkomensontwikkelingen in Amsterdam. Retrieved from http://www.os.amsterdam.nl

Bureau Onderzoek en Statistiek. (2013). Stadsdelen in cijfers 2013. Amsterdam. Retrieved from http://www.os.amsterdam.nl

Bureau Onderzoek en Statistiek. (2014). Kerncijfers inkomen naar stadsdelen. Retrieved from http://www.os.amsterdam.nl

Button, K. J., Fowkes, A. S., and Pearman, A. D. (1980). Car ownership in West Yorkshire: The influence of public transport accessibility. Urban Studies, 17(2), 211-216.

Cition. (2014). Parkeertarieven. Retrevied from https://www.cition.nl/

Clark, S. D. (2007). Estimating local car ownership models. Journal of Transport Geography, 15(3), 184197.

Cullinane, S. (2002). The relationship between car ownership and public transport provision: A case study of Hong Kong. Transport Policy, 9(1), 29-39.

Cullinane, S., and Cullinane, K. (2003). Car dependence in a public transport dominated city: Evidence from Hong Kong. Transportation Research Part D: Transport and Environment, 8(2), 129-138.

Dargay, J., and Gately, D. (1999). Income's effect on car and vehicle ownership, worldwide: 1960-2015. Transportation Research Part A: Policy and Practice. 33(2), 101-138.

Dargay, J., Gately, D., and Sommer, M. (2007). Vehicle ownership and income growth, worldwide: 19602030. Energy Journal, 28(4), 143-170. 
Dargay, J. M. (2002). Determinants of car ownership in rural and urban areas: A pseudo-panel analysis. Transportation Research Part E: Logistics and Transportation Review, 38(5), 351-366.

Denktank Markt en Overheid. (2011). Woonmanifest Amsterdam 2012.

Frankena, M. (1973). Income distributional effects of urban transit subsidies. Transport Economics and Policy, 215-230.

Gemeente Amsterdam. (2000). Parkeren is manoeuvreren. Dienst Infrastructuur, Verkeer en Vervoer.

Gemeente Amsterdam. (2011). Amsterdam in cijfers 2011. Dienst Infrastructuur, Verkeer en Vervoer.

Giuliano, G., and Dargay, J. (2006). Car ownership, travel and land use: A comparison of the US and Great Britain. Transportation Research Part A: Policy and Practice, 40(2), 106-124.

Glaeser, E. L., and Kahn, M. E. (2004). Sprawl and urban growth. Population English Edition, 4(04), 2481-2527.

Glaeser, E. L., Kahn, M. E., and Rappaport, J. (2008). Why do the poor live in cities? The role of public transportation. Journal of Urban Economics, 63(1), 1-24.

Glazer, A., and Niskanen, E. (1992). Parking fees and congestion. Regional Science and Urban Economics.

Guo, Z. (2013). Does residential parking supply affect household car ownership? The case of New York City. Journal of Transport Geography, 26, 18-28.

Handy, S., Cao, X., and Mokhtarian, P. (2005). Correlation or causality between the built environment and travel behavior? Evidence from Northern California. Transportation Research Part D: Transport and Environment, 10(6), 427-444.

Havranek, T., Irsova, Z., and Janda, K. (2012). Demand for gasoline is more price-inelastic than commonly thought. Energy Economics, 34(1), 201-207.

Huang, B. (2007). The Use of Pseudo Panel Data for Forecasting Car Ownership. Dissertation, University of London, London.

Ingram, G., and Liu, Z. (1999). Determinants of motorization and road provision. World Bank Policy Researach Working Paper.

Koster, H. R. A., Van Ommeren, J. N., and Rietveld, P. (2014). Historic amenities, income and sorting of households. Forthcoming in Journal of Economic Geography.

LeRoy, S. F., and Sonstelie, J. (1983). Paradise lost and regained: Transportation innovation, income, and residential location. Journal of Urban Economics.

London datastore. (2014). Office for National Statistics (ONS) Population Estimates, Borough and Ward. Retrieved from http://data.london.gov.uk/

Molenda, I., and Sieg, G. (2013). Residential parking in vibrant city districts. Economics of Transportation, 2(4), 131-139.

Nibud (2015). Wat kost een auto? Retrieved from http://www.nibud.nl/consumenten/wat-kost-eenauto/

Potoglou, D., and Kanaroglou, P. S. (2008). Modelling car ownership in urban areas: a case study of Hamilton, Canada. Journal of Transport Geography, 16(1), 42-54.

Q-Park. (2014). Parkeren in Amsterdam. Retrieved from http://www.q-park.nl

Shoup, D. C. (1999). The trouble with minimum parking requirements. Transportation Research Part A: Policy and Practice, 33(7), 549-574.

Shoup, D. C. (2006). Cruising for parking. Transport Policy, 13, 479-486.

UK government. (2013). Travel by Region and Area Type of Residence (NTS99). Retrieved from https://www.gov.uk 
Van Ommeren, J., de Groote, J., and Mingardo, G. (2014). Residential parking permits and parking supply. Regional Science and Urban Economics, 45(1), 33-44.

Van Ommeren, J., Wentink, D., and Dekkers, J. (2011). The real price of parking policy. Journal of Urban Economics, 70(1), 25-31.

Verhoef, E., Nijkamp, P., and Rietveld, P. (1995). The economics of regulatory parking policies: The (im)possibilities of parking policies in traffic regulation. Transportation Research Part A: Policy and Practice.

Whelan, G. A., Wardman, M., and Daly, A. J. (2000). Is there a Limit to Car Ownership Growth? An Exploration of Household Saturation Levels Using Two Novel Approaches. Proceedings of the European Transport Annual Meeting, PTRC, London.

\section{Appendix Income and car ownership}

We investigate here whether income elasticity of car demand is specific to the location of the household. We report here district-specific income effects on car ownership and the implied income elasticities which is estimated using the specification in column (3) of Table 4 combined with information about mean car ownership which is reported in Table A1. It appears that there is little variation between districts in the value of the income elasticities, with the one-permit districts having the highest income elasticities.

We have repeated the above analysis, where we allow the income elasticities to depend on household income. Figure A1 shows that income elasticities strongly decrease with household income and it appears that income elasticity is the same for each parking district for income levels above €30,000, while income elasticities for households with an income below $€ 30,000$ tend to be substantially higher when they reside in one-permit districts.

TABLE A1 - INCOME EFFECT PER PARKING DISTRICT

\begin{tabular}{|c|c|c|c|c|}
\hline & Income $(\log )$ & $\begin{array}{c}\text { Mean } \\
\text { income }\end{array}$ & $\begin{array}{c}\text { Mean car } \\
\text { ownership }\end{array}$ & $\begin{array}{l}\text { Income } \\
\text { elasticity }\end{array}$ \\
\hline Waiting-list district & $\begin{array}{c}0.412 \\
(0.015)\end{array}$ & 2,956 & 0.520 & 0.792 \\
\hline One-permit without waiting & $\begin{array}{c}0.409 \\
(0.015)\end{array}$ & 2,762 & 0.500 & 0.818 \\
\hline Two-permits district & $\begin{array}{c}0.451 \\
(0.038)\end{array}$ & 2,932 & 0.694 & 0.649 \\
\hline Free-parking district & $\begin{array}{c}0.471 \\
(0.012) \\
\end{array}$ & 2,805 & 0.780 & 0.604 \\
\hline
\end{tabular}

Note: Standard errors are in parentheses. 


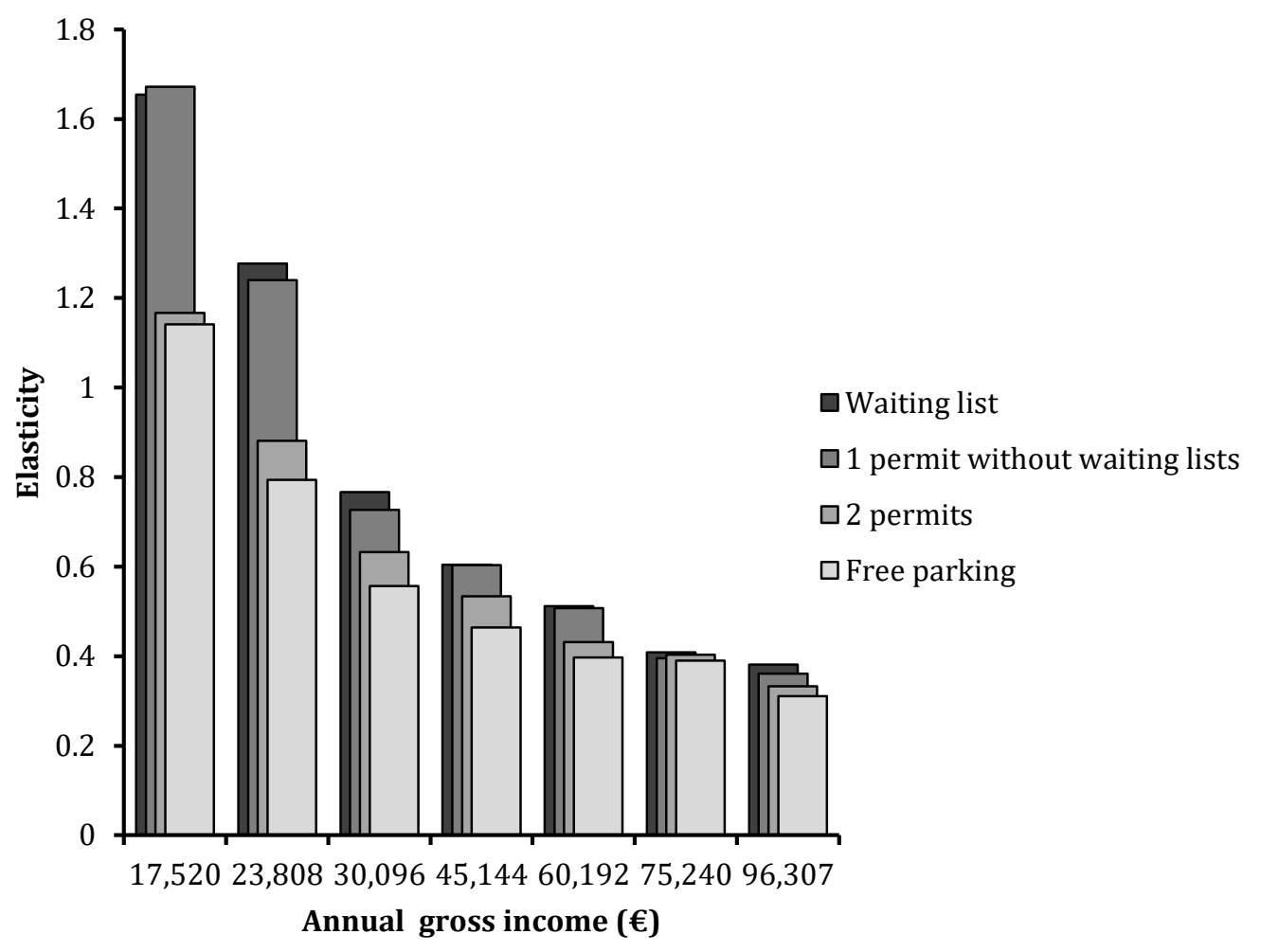

FIGURE A1 — INCOME ELASTICITY OF CAR OWNERSHIP 